
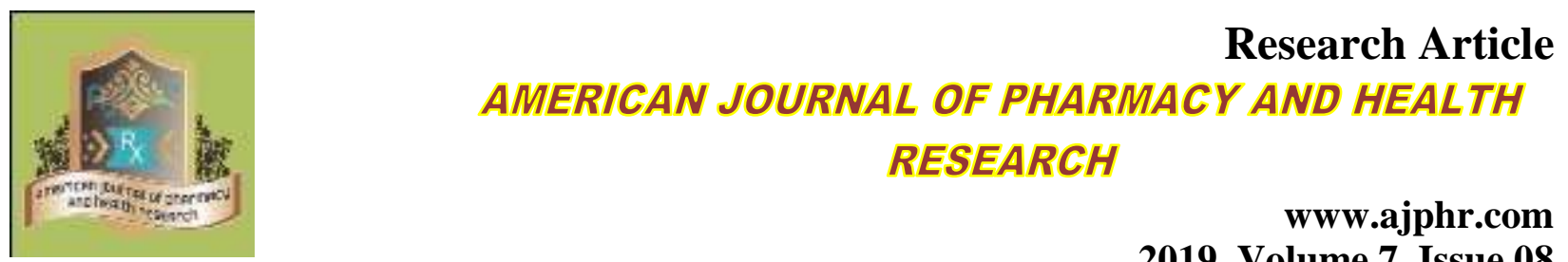

www.ajphr.com 2019, Volume 7, Issue 08 ISSN: 2321-3647(online)

\title{
Formulation and Evaluation of Antihypertensive Bilayer Tablet
}

\author{
Ganesh Deokate, Deshmukh MT, Shete RV \\ Rajgad Dnyanpeeth's College Of Pharmacy Bhor, Tal-Malshirsa, Dist-Solapur
}

\begin{abstract}
The present research work was carried out to Formulate and evaluation of Bilayer tablet dosage form for the treatment of Hypertensions. The objective of this study to compare the specific characteristics of Olmesartan midoxomil [Angiotensin II receptor antagonist] and Hydrochlorothiazide [Thiazide Diuretics] in order to design stable formulation. It can be concluded that Olmesartan Midoxomil [Angiotensin II receptor antagonist] and Hydrochlorothiazide [Thiazide Diuretics] were successfully formulated in combination as a Bilayer tablet form with Crosscarmellose sodium, Lactose monohydrate and microcrystalline cellulose PH101 for immediate release of both drugs. Both drugs were found to be stable in Bilayer tablet formulation and were found to be stable up to 6 months. This bilayer tablet dosage form increases the stability which may reduce loss and cost of formulation. It improves the benefits of producer, retailer and patients
\end{abstract}

Keywords: Thiazide Diuretics, Bilayer tablet

Please cite this article as: Ganesh DD., Formulation and Evaluation of Antihypertensive Bilayer Tablets. American Journal of Pharmacy \& Health Research 2019. 
*Corresponding Author Email: ganeshdeokate1993@gmail.com

Received 13 August 2019, Accepted 20 August 2019

\section{INTRODUCTION}

Tablets are solid dosage forms containing a unit dose of one or more medicament. They are intended for oral administration purpose. Some tablets are swallowed whole or after being chewed, some are dissolved or dispersion in water before administration and some are retained in mouth where the active ingredient is liberated completely. Preparation intended for administration by other routes of administration, for example, in the form of implants and passerines may also be presented in the form of tablets but because they may require special formulations, methods of manufacture or from of presentation appropriate to the particular use they may not comply with all the requirement of this monograph. Tables are obtained by compression or confection of uniform volumes of powders or granules by applying high pressure and using punches and dies. The particles to be compressed consist of one or more medicaments, with or without auxiliary substance such as diluents, binders, and disintegration agents, lubricant, glide ants and substances capable of modifying the behaviour of the medicaments in the digestive tracts. Such substances must be innocuous and therapeutically inert in the quantities present. Because of their composition, method of manufacture or intended use, tablets present variety of characteristics and consequently there are several categories of tablets. Useless otherwise stated in the individual monograph, tablets are uncoated. Where coating is permitted the monograph directs coating the statement reads Unless otherwise directed, tablets may be coated or uncoated tablet administered for oral use. Tablets are usually solid, right circulars cylinders, the end surfaces of which are flat or convex and the edges of which may be beveled, they may exist in others shapes like triangular, rectangular, etc also. They may have lines or break-marks and may bear a symbol or other markings. They are sufficiently hard to withstand handling without crumbling or breaking. Uncoated tablets may be signal-layer tablets resulting from a signal compression of particles or multi-layer tablets costing of parallel layers obtained by successive compression of particles of different compositions, no treatment is applied to such tablets after compression Any added substances are not ingredients in the digestive fluids. The addition of coloring or flavorings agents to uncoated tablets other than multi-layer tablets is not official unless permitted in the individual monograph. Uncoated tablets have the general characteristics of tablets. When a bracken section of uncoated tablet if the tablets fail to comply the discs the tablets comply the if they all six have disintegrated. 


\section{Coated tablet}

Coated tablets are covers with one or more layers mixture of various substances such as resins, gums, inactive, and insoluble fillers, sugars, plasticizes polyhydric alcohols, waxes, etc. the coating may also contain medicaments or without medicament in compression-coated tablets the coated is applied by compressing around the tablets granules prepared from tablets the coating is applied as a coating are usually applied as a solution or suspension in condition in which evaporation of the vehicle occurs. When the coating is thin, the tablets are described as a film coated. Coated tablets may contain flavoring and or one or more coloring agents permitted under the drug and cosmetic rules 1945 Coated tablets have a smooth. Usually polished and after colored. Surface: a broken sections examined under a lens shows a core surrounded by one or one more continuous layers of a different texture of the tablet.

Coated tablets other than film-coated tablets comply the test for disintegration of tablets and capsules use water a liquids medium add a disc to each tube operate the apparatus for 60 minuets unless otherwise justified and authorized and examine the state of the tablets if any has not disintegrated repeats the test on a further six tablets replacing water which $0.1 \mathrm{M}$ hydrochloric acid the tablets comply with the test if all six tablets have disintegrated in the acid medium. Film-coated tablets comply with the disintegration test pre cribbed over expect that the apparatus is operated for 30 minute unless otherwise justified and authorized. If coated tablets or film-coated tablets fail to comply because of adherence to the discs repeat the test on a further six tablets omitting the discs the tablets comply with the test if all six have disintegrate completely.

\section{The advantages of the bi-layer tablet dosage form are:}

- They are unit dosage form and compromise the greatest capabilities of all oral dosage form for the greatest dose precision and the least content variability.

- Cost is lower compared to all other oral dosage form.

- Lighter and compact.

- Easiest and cheapest to package and strip.

- Easy to swallowing with least tendency for hang-up.

- Unpleasant odour and bitter taste can be masked by coating technique.

- Suitable for large scale production.

- Greatest chemical and microbial stability over all oral dosage form.

- Product identification is easy and rapid requiring no additional steps when employing an pressed and/or identified punch face. 


\section{Disadvantages of Bi-Layer Tablet Dosage Form are:}

- Hard to swallow in case of children and insentient patients.

- Some drugs resist compression into dense compacts, owing to unstructured nature, low density character.

- Drugs with poor wetting, slow dissolution properties, optimum absorption high in GIT may be difficult to formulate or manufacture as a tablet that will still provide satisfactory or full drug bioavailability.

- Bitter testing drugs, drugs with an unpleasant odour or drugs that are sensitive to oxygen may require encapsulation or coating

\section{General properties of Bi-Layer Tablet Dosage Forms:}

- bi-layer tablet should have elegant product identity while free of defects like chips, cracks, mark, and impurity.

- Should have sufficient strength to withstand mechanical shock during its production packaging, shipping and dispensing.

- Should have the chemical and physical stability to maintain its physical characteristics over time.

- The bi-layer tablet must be able to release the medicinal agents in a probable and reproducible manner.

- Must have a chemical stability shelf life, so as not to follow adjustment of the medicinal agents.

\section{OLMESARTAN MEDOXOMIL}

IUPAC Name: (5-methyl-2-oxo-2H-1,3-dioxol-4-yl)methyl 4-(2-hydroxypropan-2-yl)-2-propyl1-(\{4-[2-(2H-1,2,3,4-tetrazol-5-yl)phenyl]phenyl $\}$ methyl)-1H-imidazole-5-carboxylate.

Olmesartan medoxomil is an orally active, selective angiotensin II receptor (type AT1) Angiotensin II antagonist. is the primary vasoactive hormone of the renin angiotensin-aldosterone system and plays a significant role in the pathophysiology of hypertension. The effects of angiotensin II include vasoconstriction, stimulation of the synthesis and release of aldosterone, cardiac stimulation and renal reabsorption of sodium. Olmesartan blocks the vasoconstrictor and aldosterone-secreting effects of angiotensin II by blocking its binding to the AT1 receptor in tissues including vascular smooth muscle and the adrenal gland. The action of olmesartan is independent of the source or route of synthesis of angiotensin II. The selective antagonism of the 
angiotensin II (AT1) receptors by olmesartan results in increases in plasma renin levels and angiotensin I and II concentrations, and some decrease in plasma aldosterone concentrations.

\section{HYDROHLOROTHIAZIDE}

IUPAC Name: Hydrochlorothiazide is 6-chloro-3,4-dihydro-2 $H$-1,2,4- benzothiadiazine-7sulphonamide 1,1-dioxide.

Hydrochlorothiazide is a thiazide diuretic. The mechanism of the Antihypertensive effect of thiazide diuretics is not fully known. Thiazides affect the renal tubular mechanisms of electrolyte reabsorption, directly increasing excretion of sodium and chloride in approximately equivalent amounts. The diuretic action of hydrochlorothiazide reduces plasma volume, increases plasma renin activity and increases aldosterone secretion, with consequent increases in urinary potassium and bicarbonate loss, and decreases in serum potassium. The renin-aldosterone link is mediated by angiotensin II and therefore co-administration of an angiotensin II receptor antagonist tends to reverse the potassium loss associated with thiazide diuretics. With hydrochlorothiazide, onset of diuresis occurs at about 2 hours and peak effect occurs at about 4 hours post-dose, whilst the action persists for approximately 6-12 hours. Epidemiological studies have shown that long-term treatment with hydrochlorothiazide monotherapy reduces the risk of cardiovascular mortality and morbidity.

\section{MATERIALS AND METHOD}

\section{List of Drugs and Excipients}

\begin{tabular}{|c|c|c|c|}
\hline No & Ingredients & Category & Mfg./Supplier \\
\hline 1 & Olmesartan Medoxomil & API & Aurobindo Pharma Ltd, India \\
\hline 2 & Hydrochlorothiazide & API & Alembic Pharmaceuticals Ltd, India \\
\hline 3 & Lactose Monohydrate & Diluent, Filler & DFE Pharma, Pune India \\
\hline 4 & Mannitol & Diluent & $\begin{array}{l}\text { Quingdao bright moon seaweed group } \\
\text { co. Ltd, Mumbai, India }\end{array}$ \\
\hline 5 & Maize starch & $\begin{array}{l}\text { Diluent, Binder, } \\
\text { Disintegrant }\end{array}$ & DFE Pharma, Pune India \\
\hline 6 & $\begin{array}{l}\text { Hydroxypropyl cellulose Klucel } \\
\text { LF }\end{array}$ & $\begin{array}{l}\text { Release- } \\
\text { modifier }\end{array}$ & Shin-Etsu Chem pvt Ltd \\
\hline 7 & $\begin{array}{l}\text { Low Substituted Hydroxypropyl } \\
\text { Cellulose LH-11 }\end{array}$ & Disintegrant & Shangdong head co. Ltd \\
\hline 8 & $\begin{array}{l}\text { Microcrystalline Cellulose PH- } \\
101\end{array}$ & $\begin{array}{l}\text { Diluent, } \\
\text { Disintegrant }\end{array}$ & Ankit pulps \& boards \\
\hline 9 & Croscarmellose Sodium & Disintegrant & DFE Pharma, Pune India \\
\hline 10 & Colloidal Silicon dioxide & $\begin{array}{l}\text { Glidant, } \\
\text { Disintegrant }\end{array}$ & Cabot Sanmer Ltd, Goa, India \\
\hline
\end{tabular}




\begin{tabular}{|c|c|c|c|}
\hline 11 & $\begin{array}{l}\text { Crospovidone (Polyplasdone XL } \\
10 \text { ) }\end{array}$ & Disintegrant & $\begin{array}{l}\text { Quazhou Jianhua Nanhang Industrial } \\
\text { co. Ltd }\end{array}$ \\
\hline 12 & $\begin{array}{l}\text { Sodium starch Glycolate } \\
\text { (Primogel) }\end{array}$ & Disintegrant & $\begin{array}{l}\text { Colorcon, } 3702 \mathrm{E}, 21^{\text {st }} \text { street } \\
\text { Indianpolis, Indiana- } 46218 \text {, USA }\end{array}$ \\
\hline 13 & Povidone (PVP K-30) & Binder & BASF Germany \\
\hline 15 & Isopropyl Alcohol & Solvent & $\begin{array}{l}\text { Deepak fertilizers \& petrochemicals } \\
\text { co. Ltd }\end{array}$ \\
\hline 16 & Methylene Chloride & Solvent & Cure medicines(I) pvt Ltd \\
\hline 17 & Purified water & Solvent & - \\
\hline 18 & Color lake of Tartrazine & Color & $\begin{array}{l}\text { Colorcon, } 3702 \text { E, } 21^{\text {st }} \text { street } \\
\text { Indianpolis, Indiana- } 46218 \text {, USA }\end{array}$ \\
\hline 19 & Color Iron red oxide & Color & Standardcon Pvt Ltd, Mumbai, India \\
\hline 20 & Color lake of Ponceau 4R & Color & Corel PharmaChem \\
\hline 21 & Magnesium Stearate & Lubricant & Ferro Corporation \\
\hline 22 & Talc & $\begin{array}{l}\text { Glidant, } \\
\text { Lubricant }\end{array}$ & $\begin{array}{l}\text { Luzenac ValChisone SPA } \\
\text { Pharmaceutical }\end{array}$ \\
\hline
\end{tabular}

\section{Sifting:}

1. Following material sifted through 40\# sieve: Olmesartan Medoxomil, Microcrystalline cellulose PH 101 and mixed together in geometric pattern in polyethylene bag.

2. Then following material sifted through 40\# sieve: Maize starch, Sodium starch glycolate (Primogel), Croscarmellose sodium, Colloidal silicon dioxide.

3. Color of Tartrazine sifted through 100\# sieve.

Dry mixing: Step 2 materials mixed in RMG for 20 min at slow speed

\section{Methods of preparation}

\section{Manufacturing procedure:}

\section{For Hydrochlorothiazide Part}

Dispensing: all materials planned in formula were approximately weighed.

Sifting:

- Following material sifted through 40\# sieve: Hydrochlorothiazide, Microcrystalline cellulose PH 101 and mixed together in geometric pattern in polyethylene bag.

- Then following material sifted through 40\# sieve: Mannitol, Crospovidone (Polyplasdone XL10) and Low Substituted Hydroxypropyl cellulose LH-11.

Dry mixing: Step 2 materials mixed in RMG for 20 min at slow speed i.e. mixer speed $150 \mathrm{rpm}$ and mixer current are 1.30 Amp.

Binder: Povidone PVP K-30 added and dissolved in 60 gm isopropyl alcohol and into added 30 gm Methylene chloride under stirring.

Granulation: Step 3 material granulated in RMG in following manner: 
Sizing: step 5 materials sifted through $10 \#$ sieve.

Drying: step 6 material dried in RFBD as follows:

Sizing: Step 7 materials sifted through 30\# sieve.

Pre-lubrication: Colloidal silicon dioxide and crosscarmellose sodium sifted through 40\# sieve.

Step 8 and 9 mixed in octagonal Blender for 20 min.

Lubrication: Step 10 material mixed with 50\# sifted Magnesium stearate in Octagonal blender for $5 \mathrm{~min}$.

\section{For Olmesartan Medoxomil Part/}

Dispensing: All materials planned in formula were approximately weighed i.e. mixer speed 150 rpm and mixer current are 1.30 Amp.

Binder:

1. $60 \mathrm{gm}$ of Purified water heated to boil and 30 gm water added separately to maize starch in

2. Polythene bag to form slurry.

3. Slurry added to boiling water under heating condition, continuous agitation done using spatula and cooked for 2-5min to form translucent paste.

4. This paste kept for cooling at room temperature.

Granulation: Step 3 material granulated in RMG using step 4 paste in following manner:

Sizing: Step 5 materials sifted through 10\# sieve.

Drying: Step 6 material dried in RFBD as follows:

Talc

Magnesium stearate

Sizing: Step 7 materials sifted through 30\# sieve.

Lubrication: Step 8 material mixed with following 60\# sifted material in Octagonal blender for 5 $\min$. 
Formulation development of Olmesartan medoxomil \& Hydrochlorothiazide Bilayer tablet

\begin{tabular}{|c|c|c|c|c|c|c|c|c|c|c|}
\hline \multicolumn{2}{|c|}{\begin{tabular}{|l|l|} 
No & Ingredients \\
\end{tabular}} & \begin{tabular}{|l} 
F1 \\
Prototype \\
\end{tabular} & $\mathbf{F 2}$ & F3 & $\mathbf{F 4}$ & F5 & F6 & F7 & & $\begin{array}{l}\text { F8, F9, F10 } \\
\text { Stability-I, II \& III }\end{array}$ \\
\hline \multicolumn{11}{|c|}{ Hydrochlorothiazide Part } \\
\hline \multicolumn{11}{|c|}{ Dry Mix } \\
\hline 1 & Hydrochlorothiazide & 12.50 & 12.50 & 12.50 & 12.50 & 12.50 & 12.50 & \multicolumn{2}{|l|}{12.50} & 12.50 \\
\hline 2 & Lactose Monohydrate & 40 & 40 & 40 & - & - & - & \multicolumn{2}{|l|}{-} & - \\
\hline 3 & Mannitol & - & - & - & 20.69 & 25.61 & 23.24 & \multicolumn{2}{|l|}{423.24} & q.s. to $75.00[33.24]$ \\
\hline 4 & Microcrystalline Cellulose PH 101 & 18.20 & 18.35 & 18.35 & 30.00 & 25.00 & 25.00 & \multicolumn{2}{|l|}{25.00} & 15.00 \\
\hline 5 & Hydroxypropyl cellulose Klucel LF & 3.00 & 3.00 & 3.00 & - & - & - & \multicolumn{2}{|l|}{-} & - \\
\hline 6 & Crospovidone (Polyplasdone XL 10) & - & - & - & 3.00 & 3.00 & 3.00 & \multicolumn{2}{|l|}{3.00} & 3.00 \\
\hline 7 & Low Substituted Hydroxypropyl Cellulose LH-11 & - & - & - & 3.00 & 3.00 & 3.00 & \multicolumn{2}{|l|}{3.00} & 3.00 \\
\hline 8 & Color lake of Ponceau 4R & 0.30 & 0.15 & - & - & 0.30 & - & \multicolumn{2}{|l|}{-} & - \\
\hline 9 & Color Iron red oxide & - & - & 0.150 & 0.30 & - & - & \multicolumn{2}{|l|}{-} & - \\
\hline \multicolumn{11}{|c|}{ Binder } \\
\hline 10 & Povidone (PVP K-30) & - & - & - & 3.00 & 3.00 & 3.00 & \multicolumn{2}{|l|}{3.00} & 3.00 \\
\hline 11 & Isopropyl Alcohol & - & - & - & q.s. & - & q.s. & \multicolumn{2}{|l|}{ q.s. } & q.s. \\
\hline 12 & Methylene Chloride & - & - & - & - & q.s. & q.s. & \multicolumn{2}{|l|}{ q.s. } & q.s. \\
\hline 13 & Purified water & q.s. & q.s. & q.s. & - & - & - & - & & - \\
\hline Pri & elubrication & & & & & & & & & \\
\hline 14 & Croscarmellose Sodium & 5.00 & 5.00 & 5.00 & 3.00 & 3.00 & 3.00 & 3.00 & & 3.00 \\
\hline 15 & Colloidal Silicon dioxide & - & - & - & 1.13 & 1.13 & 1.13 & 1.13 & & 1.13 \\
\hline 16 & Low Substituted Hydroxypropyl Cellulose LH-11 & - & - & - & 2.25 & 2.25 & - & - & & - \\
\hline & Color lake of Ponceau 4R & - & - & - & - & 0.08 & - & - & & - \\
\hline Lu & brication & & & & & & & & & \\
\hline & Magnesium Stearate & 1.00 & 1.00 & 1.00 & 1.13 & 1.13 & 1.13 & 1.13 & & 1.13 \\
\hline La & yer Weight(mg) & 80.00 & 80.00 & 80.00 & 80.00 & 75.00 & 75.00 & 75.00 & & 75.00 \\
\hline No & Ingredients & \begin{tabular}{|l} 
F1 \\
Prot
\end{tabular} & otype & F2 & F3 & F4 & F5 & F6 & F7 & $\begin{array}{l}\text { F8, F9, F10 } \\
\text { Stability-I, II \& III }\end{array}$ \\
\hline & mesartan Medoxomil Part & & & & & & & & & \\
\hline
\end{tabular}




\begin{tabular}{|c|c|c|c|c|c|c|c|c|c|}
\hline \multicolumn{10}{|l|}{ Dry Mix } \\
\hline 1 & Olmesartan Medoxomil & 20.00 & 20.00 & 20.00 & 20.00 & 20.00 & 20.00 & 20.00 & 20.00 \\
\hline 2 & Microcrystalline Cellulose PH 101 & 18.00 & 15.00 & 15.00 & 18.70 & 23.70 & 23.40 & 23.40 & q.s. to $65 \mathrm{mg}[23.40]$ \\
\hline 3 & Lactose Monohydrate & 21.000 & 24.00 & 24.00 & - & - & - & - & - \\
\hline 4 & Maize starch & - & - & - & 10.00 & 10.00 & 10.00 & 10.00 & 10.00 \\
\hline 5 & Color lake of Tartrazine & - & - & - & - & - & 0.30 & 0.30 & 0.30 \\
\hline 6 & Sodium starch Glycolate (Primogel) & - & - & - & - & - & 3.00 & 3.00 & 3.00 \\
\hline 7 & Croscarmellose Sodium & - & - & - & - & - & 3.00 & 3.00 & 3.00 \\
\hline 8 & Colloidal Silicon Dioxide & - & - & - & - & - & 1.30 & 1.30 & 1.30 \\
\hline \multicolumn{10}{|l|}{ Binder } \\
\hline 9 & Maize starch & - & - & - & 2.60 & 2.60 & 2.60 & 2.60 & 2.60 \\
\hline 10 & Purified water & q.s. & q.s. & q.s. & q.s. & q.s. & q.s. & q.s. & q.s. \\
\hline \multicolumn{10}{|l|}{ Prelubrication } \\
\hline 11 & Sodium starch Glycolate (Primogel) & - & - & - & 3.00 & 3.00 & - & - & - \\
\hline 12 & Croscarmellose Sodium & - & - & - & 3.00 & 3.00 & - & - & - \\
\hline 13 & Colloidal Silicon Dioxide & - & - & - & 1.30 & 1.30 & - & - & - \\
\hline \multicolumn{10}{|l|}{ Lubrication } \\
\hline 14 & Talc & - & - & - & 0.70 & 0.70 & 0.70 & 0.70 & 0.70 \\
\hline 15 & Magnesium Stearate & 1.00 & 1.00 & 1.00 & 0.70 & 0.70 & 0.70 & 0.70 & 0.70 \\
\hline Layer Weight(mg) & & 60.00 & 60.00 & 60.00 & 60.00 & 65.00 & 65.00 & 65.00 & 65.00 \\
\hline
\end{tabular}




\section{EVALUATION OF BILAYER TABLETS}

\section{Evaluation of Tablets}

Evaluation of pre-compression parameters ${ }^{[28]}$

\section{Total Moisture Content:}

Weighed amount of powder (1g) was placed on the IR balance of LOD apparatus METTLER TOLEDO HG-63 Halogen at $105^{\circ} \mathrm{C}$ and the amount of moisture in the granules was determined.

Acceptance criteria: the LOD of the granules should be between 2-3\%.

Bulk Density:

Acurately weighed quantity of dried granules into graduated $100 \mathrm{ml}$ measuring cylinder, volume was noted and Bulk Density was calculated by given formula.

$$
\text { Bulk Density }=\frac{\text { Weight of the untapped powder }}{\text { Volume of the untapped powder }}
$$

Tapped Density:

It was determined by placing a graduated $100 \mathrm{ml}$ measuring cylinder, containing a known mass of dried granules. The cylinder was allowed to fall under its own weight onto a hard surface from the height of $10 \mathrm{~cm}$ at second interval for 100 taps to obtain constant volume of powder bed. The final volume was noted and Tapped Density was calculated using the following formula.

$$
\text { Tapped Density }=\frac{\text { Weight of the tapped powder }}{\text { Volume of the tapped powder }}
$$

\section{Carr's Compressibility Index:}

The flow property of the granules was determined by \% Carr's Index. It was calculated by following formula

$$
\text { (\%)Carr's Index }=\frac{\text { Tapped Density }- \text { Bulk Density }}{\text { Tapped Density }} \times 100
$$

\section{USP limits for Carr's Compressibility Index}

\section{Hausner's Ratio:}

\begin{tabular}{lll}
\hline Sr. No. & Compressibility Index & Flow Property \\
\hline 1 & $<10$ & Excellent \\
2 & $11-15$ & Good \\
3 & $16-20$ & Fair \\
4 & $21-25$ & Passable \\
5 & $26-31$ & Poor \\
6 & $32-37$ & Very poor \\
7 & $>38$ & Very very poor \\
\hline
\end{tabular}

Hausner's Ration is an indication of flow ability of the granules. It was calculated by following formula 


$$
\text { Hausner's Ratio }=\frac{\text { Tapped Density }}{\text { Bulk Density }}
$$

\section{USP limits for Hausner's ratio}

Sieve Analysis:

\begin{tabular}{lll}
\hline Sr. No. & Hausner's Ratio & Flow Property \\
\hline 1 & $1.00-1.11$ & Excellent \\
2 & $1.12-1.18$ & Good \\
3 & $1.19-1.25$ & Fair \\
4 & $1.26-1.34$ & Passable \\
5 & $1.35-1.45$ & Poor \\
6 & $1.46-1.59$ & Very poor \\
7 & $>1.60$ & Very very poor \\
\hline
\end{tabular}

Sieve Analysis was used to determine Particle size of granules. Procedure was same as per Particle size determination of API mentioned in Chapter 6.2.1.F

\section{Evaluation of post-compression parameters ${ }^{[29]}$}

\section{In Process Quality Control Test}

Weight variation:

Twenty tablets were selected randomly from the lot and weighed individually to check for weight variation. Average weight of tablets was determined and compared with average weight the positive and negative deviation. The tablets meet USP specification if no more than 2 tablets are outside the percentage limit and if no tablets differ by more than 2 than the percentage limit.

Thickness:

Thickness of tablet is important for uniformity of tablets size. Thickness was measured using Digital Vernier Caliper. Thickness of tablet was checked after compression.

\section{Hardness:}

The resistance of tablets to shipping or breakage, under conditions of storage, transportation and handling before usage, depends on its hardness. The Hardness of the prepared tablets of each formulation was determined using a PHARMA TEST (PTB-411) hardness tester. Ten tablets were tested for hardness from hardness from each batch and mean and SD were calculated. It was measured in terms of $\mathrm{Kp}$.

Friability:

Friability is the measurement of tablet strength. (EF-2) ELECTROLAB friability tester was used for testing the friability. $6.5 \mathrm{~g}$ tablets were weighed accurately and placed in the friabilator that revolves at $25 \mathrm{rpm}$ for $4 \mathrm{~min}$ dropping the tablets through a distance of six inches 
with each revolution. After 100 revolutions the tablets were removed and dedusted, reweighed and the percentage loss in tablets weight was determined.

Disintegration Time:

In vitro disintegration time of the prepared tablets was carried out at $\left(37 \pm 2^{\circ} \mathrm{C}\right)$ in $900 \mathrm{ml}$ distilled water using a disintegration test apparatus (Electrolab-ED-2L). 6 tablets were selected randomly and placed in each basket, and machine was started. The time at which complete tablet get disintegrated was recorded as disintegration time of the tablet.

Assay and Relative substances (By HPLC) ${ }^{[30]}$

Chromatographic system

Apparatus:- HPLC, PDA detector, column-C $18,250 \mathrm{~mm} \times 4.6 \mathrm{~mm}, 5 \mu$ Inertsil ODS 3V, column temperature-Ambient, flow rate-1.0ml/min, Injection volume-20 $\mu \mathrm{L}$, wavelength-237 nm, Run time-15 min, Instrument set up, Isocratic.

Mobile Phase:- A mixture of methanol: water in the ratio of 75:25\% v/v was used as mobile phase. Mixed solvents were filtered through $0.2 \mu \mathrm{m}$ cellulose acetate membrane filters (Sartorius Ste-dim Biotech S.A.Aubagne Cedex, France) with a solvent filtration apparatus, degassed and used as mobile phase. Same was used as diluents for the preparation of drug solutions.

Preparation of 0.1M Ammonium acetate buffer:- Accurately accurate amount of ammonium acetate is dissolved in $1000 \mathrm{ml}$ water, mixed well.

Diluent blank preparation: - Mobile phase used as diluent blank.

Standard preparation: -

Stock solution of Olmesartan Medoxomil: Weighed accurate 10mg amount of Olmesartan Medoxomil sample working standard into $10 \mathrm{ml}$ clean and dry volumetric flask and added about $7 \mathrm{ml}$ of mobile phase, sonicated to dissolve and diluted to volume with mobile phase.

Stock solution of Hydrochlorothiazide: Weighed and transferred accurately about $20 \mathrm{mg}$ of Hydrochlorothiazide working standard into $10 \mathrm{ml}$ clean and dry volumetric flask and the volume was made up to with mobile phase. The containers used for storage were screw-capped tubes coated externally by aluminium foil.

\section{Sample Preparation:}

Weighed and transfer 20 whole tablets (equivalent to about $10 \mathrm{mg}$ of Olmesartan Medoxomil) into a $10 \mathrm{ml}$ volumetric flask, dissolving in the mobile phase, sonicated for about 10 minutes with intermittent shaking, diluted with mobile phase to volume and mixed well. Filter the solution through $0.45 \mu$ nylon membrane syringe filter. Transfer $5 \mathrm{ml}$ of filtrate to a $50 \mathrm{ml}$ volumetric flask 
and to volume with mobile phase. The solution was used for the estimation of Olmesartan Medoxomil and Hydrochlorothiazide $(100 \mu \mathrm{g} / \mathrm{ml})$.

\section{In-vitro drug release (Dissolution) Study ${ }^{[31,13,23]}$}

In vitro drug release studies of all the formulations were carried out using tablets dissolution test apparatus (USP type-II) at $75 \mathrm{rpm}$. Phosphate buffer $900 \mathrm{ml}, \mathrm{pH} 6.8$ was used as the dissolution media with temperature maintained at $\left(37 \pm 0.5^{\circ} \mathrm{C}\right)$. Samples $(5 \mathrm{ml})$ were withdrawn at $60 \mathrm{~min}$, filtered, diluted suitably and analyzed by HPLC system.

\section{Stability Study}

Introduction: In any rational drug design or evaluation of dosage forms, the stability of the active component must be major criteria in determining their acceptance or rejection. Stability of a drug can be defined as the time from the date of manufacture and the packaging of the formulation, until its chemical or biological activity is not less than a predetermined level of labeled potency and its physical characteristics have not changed appreciably or deleteriously.

\section{Objective of the Study}

The purpose of the testing is to provide evidence on how the quality of a drug substance or drug product varies with time under the influence of a variety of environmental factors such as temperature, humidity and light, enabling recommended storage conditions, re-test periods and shelf-lives.

The International Conference on Harmonization (ICH) Guidelines titled "Stability Testing of New Drug Products" (QIC) describes the stability test requirements for drug registration applications in the European Union, Japan and the United States of America.

ICH specifies the length of study and storage conditions.

Accelerated Testing: $40 \pm 2^{\circ} \mathrm{C} / 75 \pm 5 \% \mathrm{RH}$ for 6 months.

Intermediate Testing: $30 \pm 2^{\circ} \mathrm{C} / 65 \pm 5 \% \mathrm{RH}$ for 6 months.

Long-term Testing: $25 \pm 2^{\circ} \mathrm{C} / 60 \pm 5 \% \mathrm{RH}$ for 12 months

RESULTS AND DISCUSSION

\section{Preformulation Study}

Characterization of API

Result for Characterization of API

\begin{tabular}{llll}
\hline Sr. No. & Characterization & Olmesartan midoxomil & Hydrochlorothiazide \\
\hline 1 & Color & White to off-white & White \\
2 & Odor & Odorless & Odorless \\
\hline
\end{tabular}


Solubility Study

\section{Result for Solubility of API}

\begin{tabular}{lll}
\hline Sr. No. & Characterization & Solubility \\
\hline 1 & Olmesartan midoxomil & $\begin{array}{l}\text { Soluble in methanol, ethanol and } \\
\text { acetonitrile and insoluble in water. }\end{array}$ \\
2 & Hydrochlorothiazide & $\begin{array}{l}\text { Soluble in acetone, methanol. } \text { sparingly } \\
\text { soluble in ethanol (95\%); very slightly } \\
\text { soluble in water. }\end{array}$
\end{tabular}

Melting point Determination

Table 15: Result for Melting point determination of API

\begin{tabular}{llll}
\hline Sr. No. & Characterization & \multicolumn{2}{c}{ Melting point } \\
& & Observed & Reference \\
\hline 1 & Olmesartan midoxomil & $176-178^{\circ} \mathrm{C}$ & $178^{\circ} \mathrm{C}$ \\
2 & Hydrochlorothiazide & $274-276^{\circ} \mathrm{C}$ & $274^{\circ} \mathrm{C}$ \\
\hline
\end{tabular}

UV Spectrophotometry Study:

$\lambda_{\max }$ Determination.

Result for $\lambda_{\max }$ determination of API

\begin{tabular}{llll}
\hline $\begin{array}{l}\text { Sr. } \\
\text { No. }\end{array}$ & API & $\begin{array}{l}\lambda_{\max } \\
\text { Observed }\end{array}$ & Reference \\
\hline 1 & Olmesartan midoxomil & $231.00 \mathrm{~nm}$ & $231.00 \mathrm{~nm}$ \\
2 & Hydrochlorothiazide & $283.00 \mathrm{~nm}$ & $283.00 \mathrm{~nm}$ \\
\hline
\end{tabular}

\section{Preparation of Calibration Curve}

\section{For OLMESARTAN MIDOXOMIL}

Absorbance values at various concentration of Olmesartan Mioxomil in Methanol

\begin{tabular}{lll}
\hline Sr. No. & $\begin{array}{l}\text { Concentration } \\
(\boldsymbol{\mu g} / \mathbf{m l})\end{array}$ & Absorbance \\
\hline 1 & 0 & 0 \\
2 & 4 & 0.188 \\
3 & 8 & 0.312 \\
4 & 12 & 0.488 \\
5 & 16 & 0.644 \\
6 & 20 & 0.799 \\
\hline
\end{tabular}

\section{For HYDROCHLOROTHIAZIDE}

Absorbance values at various concentrations of Hydrochlorothiazide in methanol

\begin{tabular}{lll}
\hline Sr. No. & $\begin{array}{l}\text { Concentration } \\
(\boldsymbol{\mu g} / \mathbf{m l})\end{array}$ & Absorbance \\
\hline 1 & 0 & 0 \\
2 & 4 & 0.166 \\
3 & 8 & 0.323 \\
4 & 12 & 0.483 \\
5 & 16 & 0.637 \\
6 & 20 & 0.804 \\
\hline
\end{tabular}




\section{FTIR Study}

\section{Olmesartan midoxomil}

Interpretation of FTIR spectrum of Olmesartan midoxomil

\begin{tabular}{llll}
\hline Sr. No. & Frequency $\left(\mathbf{c m}^{-1}\right)$ & Description & Mode of Vibration \\
\hline 1 & 3461 & $-\mathrm{N}-\mathrm{H}, \mathrm{O}-\mathrm{H}$ & Stretching \\
2 & 2981,2949 & Aliphatic $-\mathrm{C}-\mathrm{H}$ & Stretching \\
3 & 2629,2358 & N-H & Stretching \\
4 & 1743 & Acid C=O Aromatic $-\mathrm{C}=\mathrm{C}$ & Stretching \\
5 & 1601 & Aromatic $-\mathrm{C}=\mathrm{C}$ & Stretching \\
6 & $1496,1382,1357$ & Aliphatic $-\mathrm{C}-\mathrm{H}$ & Bending \\
7 & 1319 & $-\mathrm{C}-\mathrm{N}$ & Stretching \\
8 & 1135 & Ether C-O & Stretching \\
9 & 1092 & Aromatic C-Cl & Stretching \\
10 & $805,757,699$ & Aromatic C-H & Stretching \\
\hline
\end{tabular}

FTIR Chromatogram of OLMESARTAN MIDOXOMIL

\section{Hydrochlorothiazide}

Interpretation of FTIR spectrum of Hydrochlorothiazide

\begin{tabular}{llll}
\hline Sr. No. & Frequency $\left(\mathbf{c m}^{-\mathbf{1}}\right)$ & Description & Mode of Vibration \\
\hline 1 & 3392 & O-H & Stretching \\
2 & 3058 & Aromatic - C-H & Stretching \\
3 & 2975,2928 & Aliphatic - C-H & Stretching \\
4 & $1637,1607,1594,1497$ & - C=C & Stretching \\
5 & 1563,1408 & $-\mathrm{C}=\mathrm{O}$ & Stretching \\
6 & 1440,1341 & Aliphatic -C-H & Bending \\
7 & 1440,1341 & Aliphatic -C-H & Bending \\
8 & 1144 & $-\mathrm{C}=\mathrm{O}$ & Stretching \\
9 & 1068 & $-\mathrm{C}-\mathrm{Cl}$ & Stretching \\
10 & $963,837,761$ & $-\mathrm{C}-\mathrm{H}$ & Bending \\
\hline
\end{tabular}

\section{FTIR Chromatogram of HYDROCHLOROTHIAZIDE}

\section{Particle size Determination of API}

Particle size analysis of API by Sieve analysis

\section{Evaluation of Tablets}

\begin{tabular}{lll}
\hline Sieve No. & \% Weight retained on sieve \\
& Olmesartan midoxomil & Hydrochlorothiazide \\
\hline$\# 20$ & 17.40 & 14.16 \\
$\# 40$ & 47.56 & 51.52 \\
$\# 60$ & 04.12 & 03.89 \\
$\# 80$ & 05.22 & 04.88 \\
$\# 100$ & 06.02 & 04.12 \\
Pan & 19.68 & 21.43 \\
\hline
\end{tabular}

Evaluation of pre-compression parameters

DRY MIX 
Ganesh., Am. J. Pharm Health Res 2019;7(08) ISSN: 2321-3647

Pre-compression parameter of Dry mix of Hydrochlorothiazide and Olmesartan midoxomil

\begin{tabular}{|c|c|c|c|c|c|c|c|c|}
\hline \multirow[t]{3}{*}{ Batch } & \multicolumn{4}{|c|}{ HYDROCHLOROTHIAZIDE } & \multicolumn{4}{|c|}{ OLMESARTAN MIDOXOMIL } \\
\hline & \multirow{2}{*}{$\begin{array}{l}\text { Bulk } \\
\text { density } \\
(\mathrm{g} / \mathrm{ml})\end{array}$} & \multicolumn{2}{|c|}{ Weight } & \multirow{2}{*}{$\begin{array}{l}\text { Loss on } \\
\text { Drying } \\
(\% \text { w/w })\end{array}$} & \multirow{2}{*}{$\begin{array}{l}\text { Bulk } \\
\text { density } \\
(\mathrm{g} / \mathrm{ml})\end{array}$} & \multicolumn{2}{|c|}{ Weight } & \multirow{2}{*}{$\begin{array}{l}\text { Loss on } \\
\text { Drying } \\
(\% \mathrm{w} / \mathrm{w})\end{array}$} \\
\hline & & Theoretical(g) & $\operatorname{Actual}(g)$ & & & Theoretical(g) & $\operatorname{Actual}(g)$ & \\
\hline F1 & 0.5380 & 79.00 & 77.09 & 2.69 & 0.3990 & 59.00 & 57.81 & 2.32 \\
\hline $\mathrm{F} 2$ & 0.4785 & 79.00 & 76.21 & 2.46 & 0.3569 & 59.00 & 56.93 & 2.04 \\
\hline $\mathrm{F} 3$ & 0.5102 & 118.00 & 116.21 & 3.14 & 0.3837 & 158.00 & 157.21 & 3.02 \\
\hline $\mathrm{F} 4$ & 0.4300 & 69.49 & 68.11 & 2.19 & 0.4000 & 48.70 & 46.94 & 2.26 \\
\hline F5 & 0.5236 & 64.44 & 63.18 & 1.65 & 0.3854 & 43.46 & 41.94 & 1.34 \\
\hline F6 & 0.4564 & 66.74 & 65.19 & 3.46 & 0.3800 & 61.00 & 59.64 & 6.47 \\
\hline F7 & 0.4860 & 200.22 & 198.16 & 2.64 & 0.3614 & 183.00 & 181.48 & 6.05 \\
\hline F8 & 0.4500 & 183.00 & 181.11 & 4.47 & 0.5000 & 200.22 & 199.02 & 2.34 \\
\hline F9 & 0.4342 & 200.22 & 198.31 & 2.30 & 0.4838 & 183.00 & 181.05 & 5.26 \\
\hline F10 & 0.4450 & 200.22 & 197.94 & 1.86 & 0.4854 & 183.00 & 181.39 & 4.41 \\
\hline
\end{tabular}

\section{DRY GRANULES}

Pre-compression parameter of Dry Granules of Hydrochlorothiazide and Olmesartan midoxomil

\begin{tabular}{|c|c|c|c|c|c|c|}
\hline \multirow[t]{3}{*}{ Batch } & \multicolumn{3}{|c|}{ HYDROCHLOROTHIAZIDE } & \multicolumn{3}{|c|}{ OLMESARTAN MIDOXOMIL } \\
\hline & \multicolumn{2}{|l|}{ Weight } & \multirow{2}{*}{$\begin{array}{l}\text { Loss } \\
\text { Drying } \\
(\% \text { w/w })\end{array}$} & \multicolumn{2}{|l|}{ Weight } & \multirow{2}{*}{$\begin{array}{l}\text { Loss } \\
\text { Drying } \\
(\% \text { w/w })\end{array}$} \\
\hline & Theoretical(g) & $\operatorname{Actual}(g)$ & & Theoretical(g) & $\operatorname{Actual}(\mathrm{g})$ & \\
\hline $\mathrm{F} 1$ & 79.00 & 77.48 & 1.57 & 59.00 & 58.12 & 2.30 \\
\hline $\mathrm{F} 2$ & 79.00 & 77.68 & 1.77 & 59.00 & 58.11 & 1.49 \\
\hline F3 & 118.00 & 117.44 & 2.36 & 158.00 & 157.69 & 1.93 \\
\hline $\mathrm{F} 4$ & 72.49 & 64.81 & 2.54 & 51.30 & 47.69 & 4.01 \\
\hline F5 & 67.44 & 63.02 & 2.39 & 56.30 & 52.42 & 4.20 \\
\hline F6 & 69.74 & 64.83 & 2.58 & 63.60 & 57.26 & 3.33 \\
\hline F7 & 209.22 & 209.91 & 3.01 & 190.80 & 173.81 & 4.26 \\
\hline F8 & 190.80 & 172.62 & 4.00 & 209.22 & 208.14 & 2.47 \\
\hline F9 & 209.22 & 199.54 & 2.95 & 190.8 & 174.85 & 3.41 \\
\hline F10 & 209.22 & 203.05 & 2.84 & 190.8 & 176.45 & 3.04 \\
\hline
\end{tabular}

\section{LUBRICATED GRANULES}

Pre-compression Parameters of Lubricated Granules of HYDROCHLOROTHIAZIDE part

\begin{tabular}{|c|c|c|c|c|c|c|c|}
\hline \multirow{2}{*}{$\begin{array}{l}\text { Batc } \\
\text { h }\end{array}$} & \multirow{2}{*}{$\begin{array}{l}\text { Bulk } \\
\text { densit } \\
\text { y } \\
(\mathrm{g} / \mathrm{ml})\end{array}$} & \multirow{2}{*}{$\begin{array}{l}\text { Tapped } \\
\text { density }(g / m l \\
)\end{array}$} & \multirow{2}{*}{$\begin{array}{l}\text { Hausner' } \\
\text { s ratio }\end{array}$} & \multirow{2}{*}{$\begin{array}{l}\text { Carr's } \\
\text { index } \\
\%\end{array}$} & \multicolumn{2}{|l|}{ Weight } & \multirow{2}{*}{$\begin{array}{l}\text { Loss on } \\
\text { Drying } \\
\text { (\%w/w } \\
\text { ) }\end{array}$} \\
\hline & & & & & $\begin{array}{l}\text { Theoretical(g } \\
\text { ) }\end{array}$ & $\begin{array}{l}\text { Actual }(\mathrm{g} \\
\text { ) }\end{array}$ & \\
\hline F1 & 0.5660 & 0.6530 & 1.1537 & $\begin{array}{l}13.323 \\
1\end{array}$ & 80.00 & 78.19 & 1.69 \\
\hline $\mathrm{F} 2$ & 0.5379 & 0.6846 & 1.2727 & $\begin{array}{l}21.428 \\
6 \\
\end{array}$ & 80.00 & 78.04 & 1.83 \\
\hline
\end{tabular}


Ganesh.,

\begin{tabular}{|c|c|c|c|c|c|c|c|}
\hline F3 & 0.5344 & 0.6108 & 1.143 & $\begin{array}{l}12.508 \\
2\end{array}$ & 120.00 & 118.13 & 2.29 \\
\hline $\mathrm{F} 4$ & 0.4500 & 0.5600 & 1.2444 & $\begin{array}{l}19.642 \\
9\end{array}$ & 80.00 & 72.63 & 2.93 \\
\hline F5 & 0.4800 & 0.6100 & 1.2708 & $\begin{array}{l}21.311 \\
5\end{array}$ & 75.00 & 70.12 & 3.59 \\
\hline F6 & 0.3700 & 0.4700 & 1.2703 & $\begin{array}{l}21.276 \\
6\end{array}$ & 75.00 & 69.48 & 3.02 \\
\hline F7 & 0.4600 & 0.5940 & 1.2913 & $\begin{array}{l}22.558 \\
9\end{array}$ & 225.00 & 213.04 & 3.15 \\
\hline $\mathrm{F} 8$ & 0.5700 & 0.7800 & 1.3684 & $\begin{array}{l}42.596 \\
7\end{array}$ & 195.00 & 178.21 & 4.31 \\
\hline F9 & 0.5277 & 0.6303 & 1.1944 & $\begin{array}{l}19.463 \\
1\end{array}$ & 225.00 & 211.23 & 3.13 \\
\hline F10 & 0.4926 & 0.5923 & 1.2024 & $\begin{array}{l}21.428 \\
6\end{array}$ & 225.00 & 215.69 & 2.75 \\
\hline \multicolumn{8}{|c|}{$\begin{array}{l}\text { Pre-compression Parameters of Lubricated Granules for OLMESARTAN MIDOXOMIL } \\
\text { part }\end{array}$} \\
\hline $\begin{array}{l}\text { Batc } \\
\text { h }\end{array}$ & $\begin{array}{l}\text { Bulk } \\
\text { densit } \\
\text { y } \\
(\mathrm{g} / \mathrm{ml})\end{array}$ & $\begin{array}{l}\text { Tapped } \\
\operatorname{density}(\mathrm{g} / \mathrm{ml} \\
\text { ) }\end{array}$ & $\begin{array}{l}\text { Hausner' } \\
\text { s ratio }\end{array}$ & $\begin{array}{l}\text { Carr's } \\
\text { index } \\
\%\end{array}$ & $\begin{array}{l}\text { Weight } \\
\text { Theoretical(g }\end{array}$ & Actual(g & $\begin{array}{l}\text { Loss on } \\
\text { Drying } \\
(\% \mathrm{w} / \mathrm{w} \\
\text { ) }\end{array}$ \\
\hline $\mathrm{F} 1$ & 0.4280 & 0.5500 & 1.2850 & $\begin{array}{l}22.181 \\
8\end{array}$ & 60 & 59.02 & 2.52 \\
\hline $\mathrm{F} 2$ & 0.4711 & 0.6909 & 1.4666 & $\begin{array}{l}31.813 \\
6\end{array}$ & 60 & 58.96 & 1.45 \\
\hline $\mathrm{F} 3$ & 0.5000 & 0.6100 & 1.2200 & $\begin{array}{l}18.032 \\
8\end{array}$ & 160 & 159.14 & 2.35 \\
\hline $\mathrm{F} 4$ & 0.5600 & 0.6400 & 1.1429 & $\begin{array}{l}12.500 \\
0\end{array}$ & 60 & 55.14 & 4.35 \\
\hline F5 & 0.5200 & 0.5900 & 1.1346 & $\begin{array}{l}11.864 \\
4\end{array}$ & 65 & 59.48 & 3.63 \\
\hline F6 & 0.4700 & 0.5400 & 1.1489 & $\begin{array}{l}12.963 \\
0\end{array}$ & 65 & 58.28 & 4.46 \\
\hline F7 & 0.4800 & 0.5942 & 1.2379 & $\begin{array}{l}19.219 \\
1\end{array}$ & 195 & 177.81 & 4.52 \\
\hline F8 & 0.4200 & 0.5200 & 1.2381 & $\begin{array}{l}14.141 \\
2\end{array}$ & 225 & 211.96 & 3.18 \\
\hline F9 & 0.4375 & 0.5600 & 1.2800 & $\begin{array}{l}19.298 \\
2\end{array}$ & 195 & 180.02 & 3.66 \\
\hline F10 & 0.47 & 0.5834 & 1.2413 & $\begin{array}{l}31.813 \\
6\end{array}$ & 195 & 180.13 & 3.90 \\
\hline
\end{tabular}

SIEVE ANALYSIS

Result for Sieve analysis for Blend of various Batches

\begin{tabular}{llllllll}
\hline Batch & Sieve Number & $\mathbf{\# 2 0}$ & $\mathbf{\# 4 0}$ & $\mathbf{\# 6 0}$ & $\mathbf{\# 8 0}$ & $\mathbf{\# 1 0 0}$ & Fines \\
\hline F1 & Hydrochlorothiazide & 0.00 & 57.23 & 16.83 & 11.05 & 4.62 & 10.27 \\
\hline
\end{tabular}




\begin{tabular}{llllllll}
\hline & Olmesartan Midoxomil & 0.00 & 57.03 & 14.45 & 14.93 & 5.56 & 8.03 \\
F2 & Hydrochlorothiazide & 0.00 & 46.38 & 20.30 & 20.54 & 3.40 & 9.38 \\
& Olmesartan Midoxomil & 0.00 & 14.27 & 8.23 & 9.63 & 8.64 & 59.23 \\
F3 & Hydrochlorothiazide & 0.00 & 59.35 & 18.73 & 10.53 & 6.50 & 4.89 \\
& Olmesartan Midoxomil & 0.00 & 43.39 & 20.06 & 19.19 & 3.33 & 14.03 \\
F4 & Hydrochlorothiazide & 0.00 & 48.65 & 16.23 & 9.70 & 3.89 & 21.53 \\
& Olmesartan Midoxomil & 0.00 & 60.16 & 18.64 & 16.8 & 1.60 & 2.80 \\
F5 & Hydrochlorothiazide & 0.00 & 12.73 & 8.53 & 15.24 & 7.93 & 55.57 \\
& Olmesartan Midoxomil & 0.00 & 67.23 & 21.18 & 9.82 & 0.85 & 0.92 \\
F6 & Hydrochlorothiazide & 0.00 & 54.82 & 24.63 & 15.27 & 1.53 & 3.75 \\
& Olmesartan Midoxomil & 0.00 & 27.40 & 15.15 & 21.53 & 7.91 & 28.01 \\
F7 & Hydrochlorothiazide & 0.00 & 21.24 & 15.94 & 17.55 & 20.37 & 24.90 \\
& Olmesartan Midoxomil & 0.00 & 28.85 & 19.64 & 16.81 & 8.76 & 25.94 \\
F8 & Hydrochlorothiazide & 0.00 & 20.82 & 16.92 & 16.05 & 22.91 & 23.30 \\
& Olmesartan Midoxomil & 0.00 & 30.09 & 17.54 & 14.70 & 5.66 & 32.01 \\
F9 & Hydrochlorothiazide & 0.00 & 37.63 & 17.64 & 12.94 & 4.53 & 27.26 \\
& Olmesartan Midoxomil & 0.00 & 16.46 & 11.56 & 22.02 & 10.75 & 39.21 \\
F10 & Hydrochlorothiazide & 0.00 & 36.22 & 15.99 & 10.28 & 6.98 & 30.53 \\
& Olmesartan Midoxomil & 0.00 & 18.43 & 13.23 & 19.63 & 9.14 & 39.57 \\
\hline
\end{tabular}

Evaluation of post-compression parameters for Bilayer Tablet

In Process Quality Control Test

Post-compression Evaluation parameters for Bilayer tablet

\begin{tabular}{lllllll}
\hline \multicolumn{2}{l}{ Batch } & \multicolumn{2}{l}{$\begin{array}{l}\text { Target weight } \\
(\mathbf{m g})\end{array}$} & $\begin{array}{l}\text { Thickness } \\
(\mathbf{m m})\end{array}$ & Hardness (kp) & D.T.(min) \\
\cline { 1 - 5 } No. & Type & Size & & & \\
\hline F1 & Prototype & 1000 Tab & $140 \pm 5 \%$ & $2.6-2.7$ & $3.91-4.67$ & 8.51 \\
F2 & Trial & 1000 Tab & $140 \pm 5 \%$ & $2.7-2.8$ & $3.29-4.01$ & 5.12 \\
F3 & Trial & 2000 Tab & $140 \pm 5 \%$ & $2.6-2.7$ & $3.56-4.15$ & 4.36 \\
F4 & Trial & 1000 Tab & $140 \pm 5 \%$ & $2.9-3.0$ & $4.81-6.03$ & 6.12 \\
F5 & Trial & 1000 Tab & $140 \pm 5 \%$ & $2.7-2.8$ & $4.61-4.79$ & 5.23 \\
F6 & Trial & 1000 Tab & $140 \pm 5 \%$ & $2.6-2.7$ & $4.40-5.49$ & 7.21 \\
F7 & Trial & 3000 Tab & $140 \pm 5 \%$ & $2.6-2.7$ & 5.12 & 6.21 \\
F8 & Stability & 3000 Tab & $140 \pm 5 \%$ & $2.7-2.8$ & $5.12-5.26$ & 4.35 \\
F9 & Stability & 3000 Tab & $140 \pm 5 \%$ & $2.7-2.8$ & $4.03-5.93$ & 4.26 \\
F10 & Stability & 3000 Tab & $140 \pm 5 \%$ & $2.7-2.8$ & $3.99-5.93$ & 4.21 \\
\hline
\end{tabular}

Punch Details: $7.4 \mathrm{~mm}$ flat faced beveled edge round plain punches.

Appearance:

F1-F5= Red and white colored round shaped flat faced uncoated tablet with beveled edges plain at both sides. 
Ganesh.,

F6-F10 = Yellow and white colored round shaped flat faced uncoated tablet with beveled edges plain at both sides.

\section{Assay, \% content uniformity and In-vitro Dissolution study}

Result of Assay, In-vitro Dissolution study and \% content uniformity of trial batches given in Table 29. In this F5 Batch showing High Assay, High \% CU and Hydrochlorothiazide part gives Low Disso where Olmesartan midoxomil part gives High Disso release.

Result of Analysis for Trial batches

\begin{tabular}{|c|c|c|c|c|c|c|c|c|c|c|}
\hline & \multicolumn{2}{|l|}{ F3 } & \multicolumn{2}{|l|}{ F5 } & \multicolumn{2}{|l|}{ F6 } & \multicolumn{2}{|l|}{ F7 } \\
\hline & & & \multicolumn{8}{|l|}{ Trial } \\
\hline \multirow[t]{6}{*}{ Assay(\%) } & & & HCTZ & Olme & HCTZ & Olme & HCTZ & Olme & HCTZ & Olme \\
\hline & \multirow{3}{*}{$\begin{array}{l}\text { L.G. } \\
\text { Blend }\end{array}$} & Top & 93.45 & 106.27 & 110.91 & 105.80 & 107.16 & 106.16 & 108.04 & 103.52 \\
\hline & & Middle & 95.26 & 104.29 & 109.45 & 107.56 & 105.50 & 104.94 & 107.26 & 103.56 \\
\hline & & Bottom & 103.43 & 106.24 & 116.42 & 112.48 & 104.14 & 106.28 & 109.10 & 101.98 \\
\hline & \multicolumn{2}{|l|}{ Tablet } & 104.25 & 108.24 & 121.51 & 119.02 & 108.32 & 101.68 & 104.33 & 102.09 \\
\hline & \multicolumn{2}{|c|}{ Reference } & \multicolumn{2}{|c|}{$(90-110) \%$} & \multicolumn{2}{|c|}{$(90-110) \%$} & \multicolumn{2}{|c|}{$(90-110) \%$} & \multicolumn{2}{|c|}{$(90-110) \%$} \\
\hline \multirow{9}{*}{\multicolumn{2}{|c|}{$\begin{array}{l}\text { Dissolution } \\
\text { (NLT Q+5\%) }\end{array}$}} & & HCTZ & Olme & HCTZ & Olme & HCTZ & Olme & HCTZ & Olme \\
\hline & & & 93.24 & 114.25 & 73.91 & 113.79 & 111.64 & $105 . .46$ & 108.24 & 97.54 \\
\hline & & & 108.37 & 113.41 & 43.95 & 117.78 & 92.49 & 96.43 & 90.8 & 98.59 \\
\hline & & & 98.26 & 110.45 & 70.45 & 118.77 & 97.82 & 106.27 & 96.96 & 98.56 \\
\hline & & & 112.35 & 107.26 & 60.92 & 115.38 & 109.45 & 91.27 & 103.05 & 97.70 \\
\hline & & & 106.27 & 112.86 & 55.18 & 104.73 & 99.53 & 92.34 & 91.37 & 98.85 \\
\hline & & & 94.26 & 104.38 & 80.96 & 117.12 & 113.92 & 91.38 & 94.6 & 95.73 \\
\hline & & Mean & 102.13 & 110.44 & 64.23 & 114.6 & 104.14 & 97.19 & 97.50 & 97.83 \\
\hline & & Reference & $85-115$ & $\begin{array}{l}90- \\
110 \\
\end{array}$ & $85-115$ & $\begin{array}{l}90- \\
110\end{array}$ & $85-115$ & $90-110$ & $85-115$ & $\begin{array}{l}90- \\
110 \\
\end{array}$ \\
\hline \multirow{8}{*}{\multicolumn{2}{|c|}{$\begin{array}{l}\% \\
\text { uniformity } \\
(85-115) \%\end{array}$}} & & HCTZ & Olme & HCTZ & Olme & HCTZ & Olme & HCTZ & Olme \\
\hline & & & 96.53 & 93.43 & 119.76 & 117.69 & 112.43 & 114.84 & 113.95 & 101.44 \\
\hline & & & 106.25 & 105.27 & 114.42 & 122.40 & 111.28 & 112.47 & 112.71 & 101.09 \\
\hline & & & 98.34 & 104.38 & 118.65 & 121.74 & 110.92 & 94.43 & 113.25 & 100.97 \\
\hline & & & 113.28 & 99.25 & 118.18 & 111.76 & 108.46 & 112.15 & 113.85 & 95.29 \\
\hline & & & 109.34 & 100.83 & 123.01 & 115.30 & 114.61 & 109.68 & 112.48 & 96.72 \\
\hline & & Mean & 104.75 & 100.63 & 118.80 & 117.78 & 111.54 & 108.72 & 113.25 & 99.10 \\
\hline & & Reference & \multicolumn{2}{|c|}{$(85-115) \%$} & \multicolumn{2}{|c|}{$(85-115) \%$} & \multicolumn{2}{|c|}{$(85-115) \%$} & \multicolumn{2}{|c|}{$(85-115) \%$} \\
\hline
\end{tabular}

Assay, \% content uniformity and In-vitro Dissolution study for Stability Batches

Here at Initial Stage Stability batches F8, F9 and F10 gives the satisfactory values of Assay, \% content uniformity and In-vitro Dissolution study.

Result of Analysis for Stability batches at Initial

\begin{tabular}{|l|l|l|l|l|l|l|}
\hline Batch No. & F8 & F9 & \multicolumn{2}{|l|}{ F10 } \\
\hline & HCTZ & Olme & $\begin{array}{l}\text { HCT } \\
\text { Z }\end{array}$ & Olme & $\begin{array}{l}\text { HCT } \\
\text { Z }\end{array}$ & Olme \\
\hline
\end{tabular}


Ganesh.,

Am. J. Pharm Health Res 2019;7(08)

ISSN: 2321-3647

\begin{tabular}{|c|c|c|c|c|c|c|c|c|}
\hline \multirow[t]{5}{*}{$\begin{array}{l}\operatorname{Assay}(\% \\
)\end{array}$} & \multirow{3}{*}{$\begin{array}{l}\text { L.G. } \\
\text { Blen } \\
\text { d }\end{array}$} & Top & 102.00 & $\begin{array}{l}104.5 \\
4\end{array}$ & 108.06 & $\begin{array}{l}103.4 \\
6\end{array}$ & 108.15 & $\begin{array}{l}104.3 \\
4\end{array}$ \\
\hline & & Middle & 103.68 & $\begin{array}{l}105.9 \\
6\end{array}$ & 109.13 & $\begin{array}{l}104.9 \\
1\end{array}$ & 107.51 & $\begin{array}{l}106.1 \\
7\end{array}$ \\
\hline & & $\begin{array}{l}\text { Botto } \\
\text { m }\end{array}$ & 102.46 & $\begin{array}{l}105.8 \\
0\end{array}$ & 108.82 & $\begin{array}{l}106.4 \\
8\end{array}$ & 108.73 & $\begin{array}{l}104.3 \\
9\end{array}$ \\
\hline & \multicolumn{2}{|c|}{ Tablet } & 102.23 & 99.12 & 106.36 & $\begin{array}{l}102.5 \\
8\end{array}$ & 106.15 & 98.75 \\
\hline & \multicolumn{2}{|c|}{ Reference } & \multicolumn{2}{|c|}{$(90-110) \%$} & \multicolumn{2}{|c|}{$(90-110) \%$} & \multicolumn{2}{|c|}{$(90-110) \%$} \\
\hline \multirow{8}{*}{\multicolumn{2}{|c|}{$\begin{array}{l}\text { Dissolution } \\
\text { (NLT Q+5 \%) }\end{array}$}} & & HCTZ & Olme & $\begin{array}{l}\text { HCT } \\
\mathrm{Z}\end{array}$ & Olme & $\begin{array}{l}\text { HCT } \\
\mathrm{Z}\end{array}$ & Olme \\
\hline & & & 103.50 & 91.02 & 113.28 & 98.46 & 114.65 & 97.28 \\
\hline & & & 107.47 & 97.83 & 103.54 & 93.58 & 111.31 & 94.61 \\
\hline & & & 106.88 & 98.82 & 114.48 & 94.38 & 110.94 & 98.34 \\
\hline & & & 111.39 & 96.67 & 108.61 & 96.19 & 110.47 & 97.46 \\
\hline & & & 109.56 & 98.33 & 109.18 & 98.56 & 112.69 & 99.28 \\
\hline & & & 95.55 & 98.11 & 110.64 & $\begin{array}{l}100.0 \\
8\end{array}$ & 111.93 & 94.99 \\
\hline & & Mean & 105.73 & 96.80 & 109.96 & 96.88 & 112.00 & 97.00 \\
\hline \multicolumn{3}{|l|}{ Reference } & $85-115$ & $\begin{array}{l}90- \\
110\end{array}$ & $\begin{array}{l}85- \\
115\end{array}$ & $\begin{array}{l}90- \\
110\end{array}$ & $\begin{array}{l}85- \\
115\end{array}$ & $\begin{array}{l}90- \\
110\end{array}$ \\
\hline \multirow{7}{*}{\multicolumn{2}{|c|}{$\begin{array}{l}\% \text { content } \\
\text { uniformity } \\
(85-115) \%\end{array}$}} & & HCTZ & Olme & $\begin{array}{l}\text { HCT } \\
\mathrm{Z}\end{array}$ & Olme & $\begin{array}{l}\text { HCT } \\
\mathrm{Z}\end{array}$ & Olme \\
\hline & & & 111.35 & 97.00 & 111.14 & 96.70 & 112.32 & 95.57 \\
\hline & & & 111.85 & 96.64 & 103.81 & $\begin{array}{l}100.0 \\
5\end{array}$ & 112.81 & 96.62 \\
\hline & & & 113.94 & 97.99 & 106.53 & 99.00 & 113.93 & 96.07 \\
\hline & & & 112.60 & 98.42 & 104.83 & $\begin{array}{l}106.8 \\
4\end{array}$ & 114.31 & 96.00 \\
\hline & & & 113.79 & 98.14 & 99.51 & $\begin{array}{l}103.7 \\
8\end{array}$ & 109.60 & 91.40 \\
\hline & & Mean & 112.71 & 97.64 & 105.16 & $\begin{array}{l}101.2 \\
7 \\
\end{array}$ & 112.59 & 95.13 \\
\hline \multicolumn{3}{|l|}{ Reference } & \multicolumn{2}{|c|}{$(85-115) \%$} & \multicolumn{2}{|c|}{$(85-115) \%$} & \multicolumn{2}{|c|}{$(85-115) \%$} \\
\hline
\end{tabular}


Ganesh.,

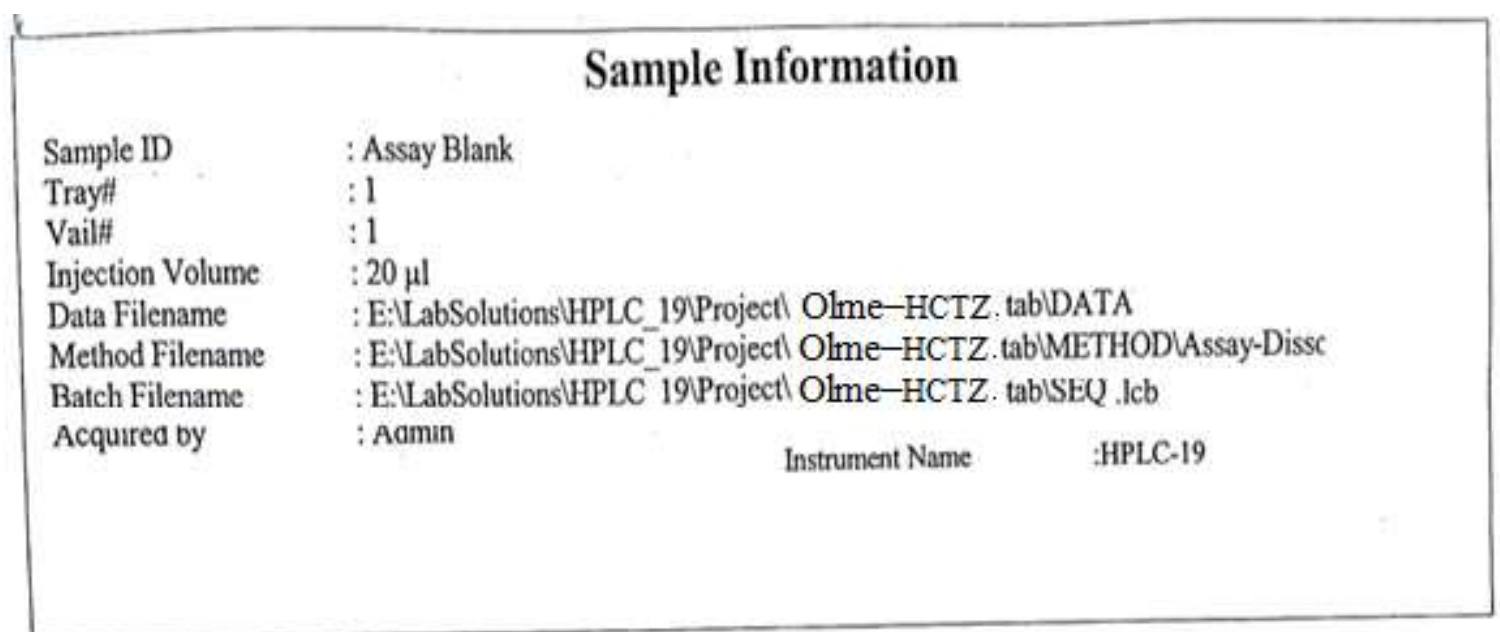

Chromatogram

Olme-HCTZ·। Tab E:LabSolutionsHPLC_19Project Olme-HCTZ·tabDATAI 101.lod

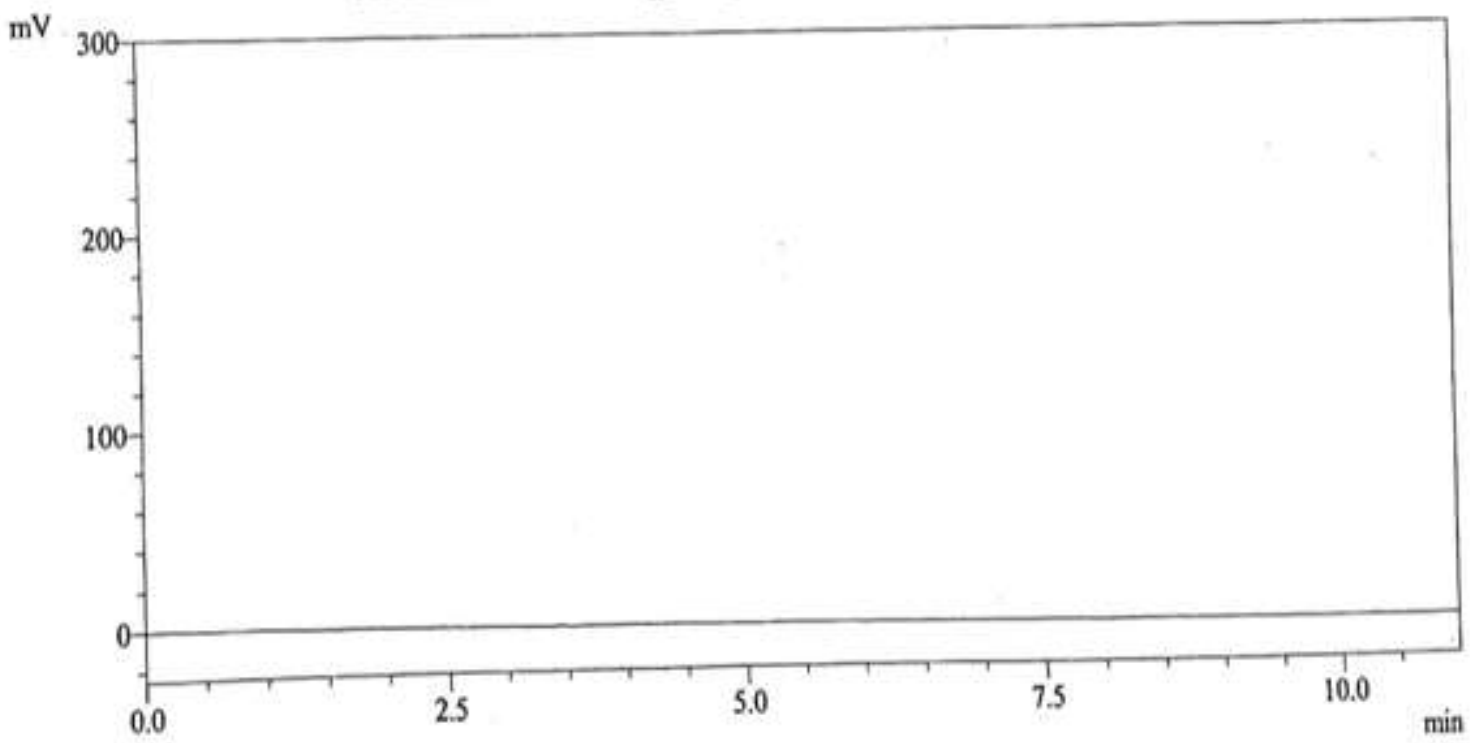

1 Det.A Chl /236nm

PeakTable

Detector A Chl 236nm

Chromatogram of Blank for Assay of Bilayer Tablet of OLMESARTAN MIDOXOMIL and HYDROCHLOROTHIAZIDE 
Ganesh.,

Am. J. Pharm Health Res 2019;7(08)

ISSN: 2321-3647

Chromatogram

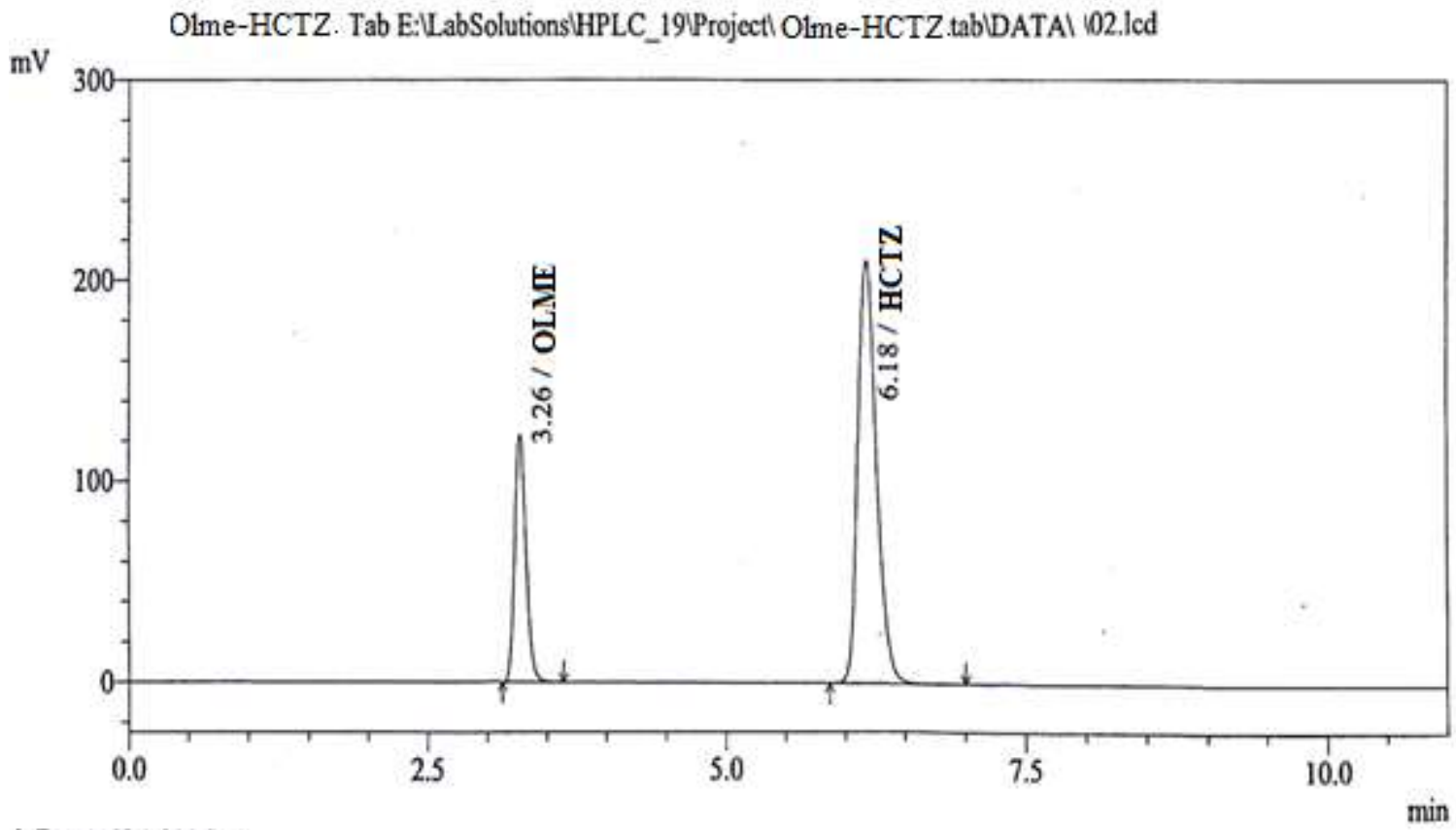

1 Det. $\mathrm{ACh} 1 / 236 \mathrm{~nm}$

Detector A Ch1 236nm
\begin{tabular}{|c|c|c|c|c|c|c|}
\hline Peak\# & Name & RT(min) & Area & Area \% & Tailing Factor & Theoretical Plate\# \\
\hline 1 & OLME & 3.264 & 809178 & 26.107 & 1.26 & 4959 \\
\hline 2 & HCTZ & 6.184 & 2290316 & 73.893 & 1.19 & 7124 \\
\hline Total & & & 3099495 & 100.000 & & \\
\hline
\end{tabular}

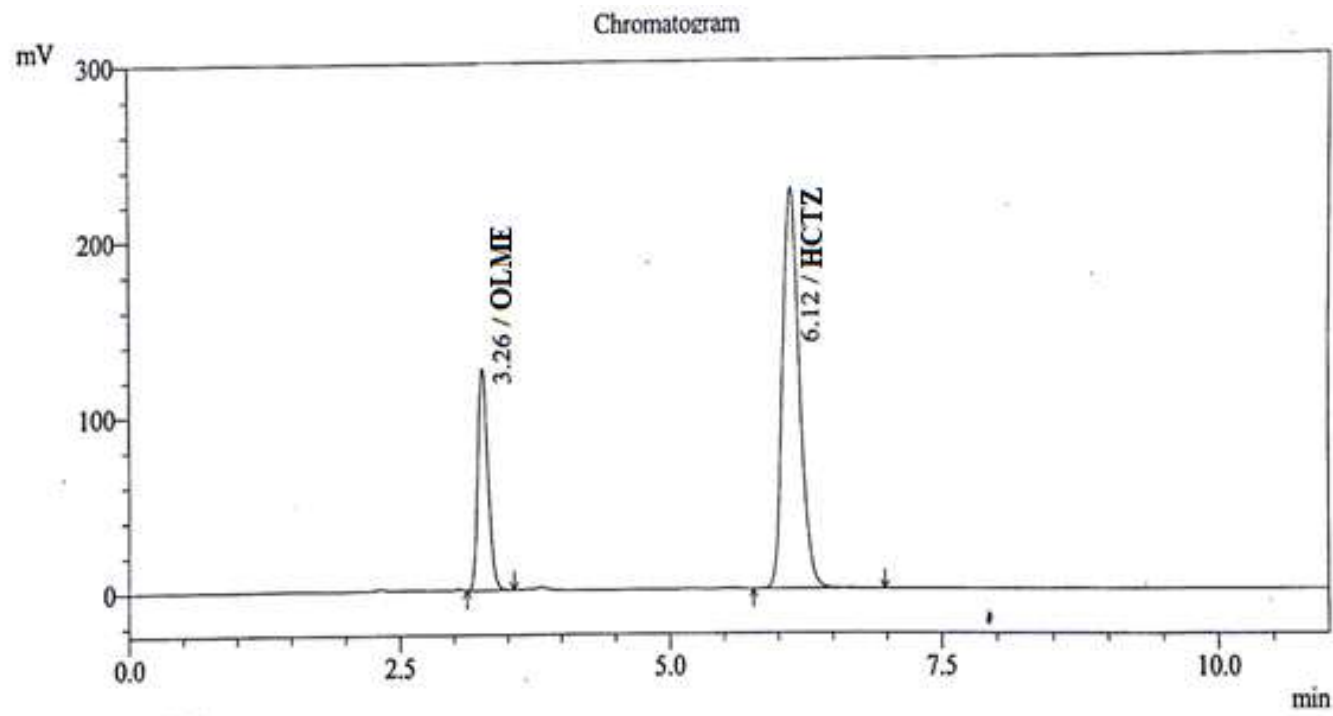

1 Det.A Chl / 236nm

Detector A Ch1 $236 \mathrm{~nm}$
\begin{tabular}{|c|c|c|c|c|c|c|}
\hline Peakd & Name & RT(min) & Area & Area $\%$ & Tailing Factor & Theoretical Plate \\
\hline 1 & OLME & 3.259 & 821311 & 25.137 & 1.25 & 5066 \\
\hline 2 & HCTZ & 6.121 & 2446063 & 74.863 & 1.18 & 7121 \\
\hline Total & & & 3267374 & 100.000 & & \\
\hline
\end{tabular}




\section{Chromatogram of Sample1 for Assay and Content Uniformity}

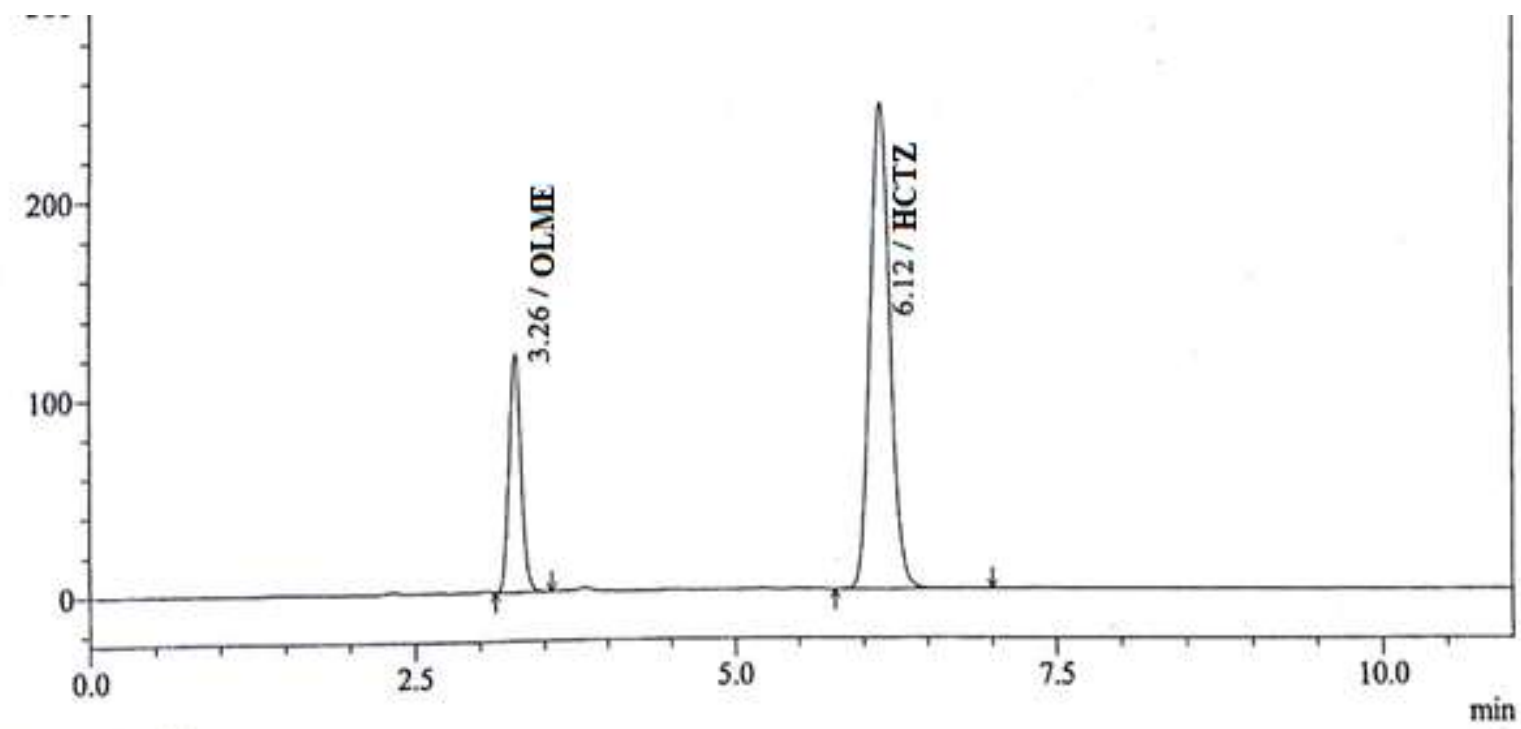

1 Det.A Ch1/236nm

\begin{tabular}{|c|c|c|c|c|c|c|}
\hline \multirow{2}{*}{\multicolumn{7}{|c|}{ Detector A Ch1 236nm }} \\
\hline & & & & & & \\
\hline Peak\#t & Name & RT(min) & Area & Area $\%$ & Tailing Factor & Theoretical Platelf \\
\hline 1 & OLME & 3.260 & 790684 & 22.816 & 1.25 & 5081 \\
\hline 2 & HCTZ & 6.118 & 2674785 & 77.184 & 1.19 & 7122 \\
\hline Total & & & 3465469 & 100.000 & & \\
\hline
\end{tabular}

\section{SUMMARY AND CONCLUSION}

This bilayer tablet dosage form increases the stability which may reduce loss and cost of formulation. It improves the benefits of producer, retailer and patients

Allergic rhinitis is a common disorder that affects large population. The treatment goals for Hypertension are relief of symptoms. Therapeutic options available to achieve this goal include various drugs. The combination Olmesartan midoxomil with Hydrochlorothiazide gives additional benefits in comparison with either drug alone and could be considered for patients whose quality of life is impaired by persistent Hypertension.

When tablets of the combination of these are prepared, they tend to become unstable during the shelf life of the formulation. Hence it is recommended to prepare a bilayer tablet; it improves and increases the stability by reducing the acid base interactions of both the drugs in combination there by increasing the bioavailability. To overcome the short coming of single layer tablet approach in this combination like bilayer can be satisfactorily used. In this study demonstrated the successful formulation and evaluation of an Antihypertensive in a single dosage form as bilayer.

The parameters like solubility, melting point, $\lambda_{\max }$ were evaluated to identify purity of drug and all parameters were found satisfactory and within prescribed official limits. Preformulation study was 
carried out. One prototype batch, six trial batches and then three stability batches for formulation and development were prepared using wet granulation and dry granulation. Excipient like Ponceau 4R and water may influence with the Hydrochlorothiazide that changes the color of tablets one part, hence we replace the color with Iron red oxide. Combination of excipient like disintegrants in Olmesartan Midoxomil part. For appropriate immediate release of Olmesartan Midoxomil Lactose were replaced with Starch, Sodium Starch Glycolate and crosscarmellose Sodium. Stability study performed as per ICH guidelines and satisfactory results were obtained which concluded that the batches F8, F9 and F10 are supposed to be stable and expected to remain for the period of three years with drugs gives the different release of drug that fixed here in this formulation for the immediate release of both drugs. F1 was planned as a wet granulation with Ponceau 4R in Hydrochlorothiazide part tablet produces color change in that. So, in F6 formulation color is added or more.

\section{REFERENCE}

1. Kamalakkannan G, et al. 2007. Fixed-Dose Combinations Improve Medication Medication Compliance, The American Journal of Medicine. 120:713-19

2. Aulton ME. 2002. Pharmaceutics: The Science of Dosage Form Design. $2^{\text {nd }}$ edition. Churchill Livingstone:133-34,398.

3. http://druginfocentre.blogspot.in/advantages-and disadvantages-of-tablets 2013.

4. Lachman L, Liberman HA, Schwartz JB. 1989. Pharmaceutical dosage forms: Tablets. 1(2):247-278.

5. Lesney, Mark S. 2013. More than just the sugar in the pill. Today's Chemist at work. 10(1); Aug13:30-6.

6. Indian Pharmacopoeia 2010, Gov. Of India, Ministry of Health and Family Welfare, The Indian Pharmacopoeia commission. Gaziabad. $6^{\text {th }}$ edition. 2010(III):158,2186-88.

7. Indian Pharmacopoeia 2007, Gov. Of India, Ministry of Health and Family Welfare, The Indian Pharmacopoeia commission. Gaziabad. 2010(II):672-73.

8. Guillory JK, Rollard I, Poust. Chemical Kinetics and drug Stability Textbook of Modern Pharmaceutics. $4^{\text {th }}$ edition:139-47.

9. Deliang Z, Qiu: 2009. Understanding Physicochemical Properties for Pharmaceutical Products Development and Manufacturing II Physical and Chemical Stability of excipient, Compatibility Journal of Validation Tech:34-36. 
10. Jens C. 1995. ICH Guidelines. Drug Stability Principles and Practices. $2^{\text {nd }}$ edition. New York: Marcel Dekker, Inc. 68:541-46.

11. Indian Pharmacopoeia 2014, Gov. Of India, Ministry of Health and Family Welfare, The Indian Pharmacopoeia commission. Gaziabad. 2014(I,II):192,256-57,2247-48.

12. Lachman L, Lieberman HA. 2009. The theory and practice of Industrial pharmacy. $3^{\text {rd }}$ edition, Varghese publishing house:171-346.

13. United State Pharmacopoeia, 35 NF-30, 2012(I):5975-5977.

14. https://health.uconn.edu/pharmacy/wpcontent/uploads/sites/60/2016/03/hf_med_handout.pdf

15. Siyad.AR. Hypertension, H.J.D.Med. vol.3(1), April-October 2011, pp.1-16.

16. Farhad Farshi et al. Pharmaceutical Formulations of Olmesartan, EP2387392A1. December 30, 2008.

17. Sathik J, Karuna DS, Rathnam G, Ubaidulla U. 2014. Development of Stable Dispersable bi-layer Tablet of Montelukast Sodium and Levocetrizine HCl. IJPDT. 4(4):237-244.

18. www.mhra.gov.uk/spc-pil/

19. Md Moiz, Srinivas P, Sadanandam M. 2011. Formulation and evaluation of bilayered tablets of montelukast and levocetrizine dihydrochloride Using natural and synthetic polymers. International Journal of Drug Delivery 3:597-618.

20. Vishwakarma AG, Mogal RT, Pawar AY. 2014. Bi-Layer Tablet- A New Ways in Oral Drug Delivery System. International Journal of PharmTech Research. 6(5):1416-1428.

21. Geetha K, Prasad D, Sudhakar M, Yasmin MB. 2014. Formulation and evaluation of Bilayered floating tablets of cefuroxime axetil. Int J Pharm,4(3):297-306.

22. Ryakala H, Dineshmohan S., Ramesh A, Gupta VRM. 2015. Formulation and In Vitro Evaluation of Bilayer Tablets of Nebivolol Hydrochloride and Nateglinide for the Treatment of Diabetes and Hypertension. Journal of Drug Delivery:1-14.

23. United State Pharmacopoeia, 29 NF-24, 2007(28):1061-1062.

24. Raymond C Rowe, Paul J Sheskey, Marian E Quinn. 2009. Handbook of Pharmaceutical Excipients. $6^{\text {th }}$ edition. RPS Publishing House.

25. British Pharmacopoeial Commission. British Pharmacopoeia 2010. London. 2010(I):A730.

26. Gurdeep RC, Sham KA. 2002. Instrumental methods of Chemical Analysis. $5^{\text {th }}$ edition. Himalaya Publishing House:2.29-2.639. 
27. Marydel, Jo Neil, The Merck Index an Encyclopedia of Chemical drug and biological 14th edition published by Merck Research laboratories Merck co, Inc white house NJ USA,9:6081.

28. Q4B Evaluation recommendation of pharmacopoeial test for use in ICH region general chapter bulk density and tapped density of powders.

29. Nancy JBL, Jackson R. 2001. Drugs used in the treatment of Asthma. Goodman Gillman A.(Eds.).The pharmacological basis of therapeutics.10 ${ }^{\text {th }}$ edition. New york: McGraw Hill:647,735-38.

30. Mohammed BI, et al. 2015. RP-HPLC Method for Simultaneous Estimation of Hydrochlorothiazide and Olmesartan Midoxomil in tablets. Indian E-Journal of Pharmaceutical Sciences. 01(01):18-20.

31. Jahufar S, et al. 2014. Development of Stable Dispersable Bi-Layer Tablet of Hydrochlorothiazide and Olmesartan Midoxomil, International Journal of Pharmaceutical Development \& Technology. 4(4):237-244.

32. Q1C ICH guideline for stability testing for new dosage forms.

33. Barar F.S.K. Essentials of pharmacotherapeutics. $4^{\text {th }}$ edition. S.Chand \& co. 1td,1985.

34. Sharma V, Chopra H. 2012. Formulation and Evaluation of Taste Masked Mouth Dissolving Tablets of Levocetirizine Hydrochloride. Iranian Journal of Pharmaceutical research. 11(2):457-463.

35. Raymond CR, Paul JS, Marian EQ. 2009. Handbook of Pharmaceutical Excipients, 6th edition, RPS Publishing.

36. Joint FAO/WHO Expert Committee on Food Additives, Compendium of Food Additive Specifications, Food and Agriculture of the united nations Rome, 2011:91-94.

\section{AJPHR is}

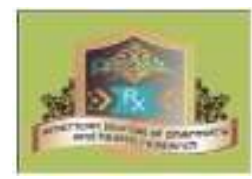

Peer-reviewed

monthly

Rapid publication

Submit your next manuscript at

editor@ajphr.com / editor.ajphr@gmail.com 